\title{
PERILAKU PETANI CABAI RAWIT TERHADAP RESIKO FLUKTUASI HARGA DI KECAMATAN GUMUKMAS KABUPATEN JEMBER
}

\author{
Aisyah Muluukhul Ardian Kurniawati', Imam Syafi'i² \& Mohammad Rondhi' \\ ${ }^{1}$ Mahasiswa, Program Studi Agribisnis Fakultas Petanian Universitas Jember \\ ${ }^{2}$ Dosen, Program Studi Agribisnis Fakultas Pertanian Universitas Jember \\ email: Muluukhulaisyah@gmail.com
}

\begin{abstract}
This study was aimed to determine the farmer's behaviour in face of risk as result of pepper's price fluctuation in Gumukmas District, Jember Regency. There are three criterias in farmer's behaviour : risk lover, risk neutral, and risk averter. Thirty-nine farmers was selected by using simple random sampling. The utility function was employed to determine farmer's behaviour. In this research, utility function with Bernoulli and Neuman -Morgerstern technique was used. This specification was modified with neutral probability (50:50). Estimation on this function was done by using uncertainty equivalent (CE) through quadratic estimation. The result showed that arround 33 farmers $(84.62 \%)$ are risk neutral. The risk averter are 5 farmers (11.52\%) and one farmer $(2.56 \%)$ is risk lover. This result also showed that farmers with own land ownership status were more daring than farmers who own land tenure status, profit sharing, or farmers who have two land ownership status. Other results indicated that the farmers who pursued local pepperwere more daring than the farmers who pursued hybrid pepper or farmers who persuedlocal and hybrid at once.
\end{abstract}

Keywords: pepper, risk lover, risk neutral, risk averter, pepper price fluctuation

\section{PENDAHULUAN}

Potensi sub-sektor hortikultura di indonesia sangat besar, meskipun dalam pengembangannya masih mengalami banyak kendala diantaranya belum ada perlindungan hukum yang kuat untuk melindungi keberadaan hortikultura. Hortikultura sendiri merupakan cabang dari agronomi yang fokus terhadap budidaya tanaman buah (frutikultura), tanaman bunga (florikultura), tanaman sayuran (olerikultura), tanaman obat (biofarma$k a$ ), dan tanaman taman (lansekap). Ciri tanaman hortikutura adalah perishabel atau mudah sekali rusak. Hal ini menjadi salah satu dari pertimbangan petani untuk mengusahakan tanaman hortikultura. Hortikultura merupakan salah satu komoditas yang terdapat dalam sektor pertanian yang memiliki potensi besar untuk dikembangkan di Jawa Timur. Beberapa komoditas yang produksinya mendominasi di Jawa Timur pada tahun 2014 adalah bawang merah, kentang, kubis, cabai rawit, dan semangka. Dalam kurun waktu 4 tahun terakhir, rata-rata produksi tertinggi hortikultura di dominasi oleh produksi bawang merah yang mencapai 293 ribu ton, kemudian produksi cabai rawit 223 ribu ton pada posisi kedua, dan kubis 204 ribu ton pada posisi ketiga (BPS Jawa
Timur, 2015). Tingginya produksi cabai rawit juga dipengaruhi oleh perkembangan produksi cabai rawit di berbagai kabupaten dan kota di Jawa Timur. Empat produksi cabai rawit terbesar terdapat diKabupaten Blitar sebesar 34,35 ribu ton, Jember sebesar 32,12 ribu ton, Lumajang sebesar 23,40 ribu ton dan Kediri sebesar 22,42 ribu ton pada tahun 2014. Berdasarkan empat kabupaten tersebut diatas peningkatan produksi cabai rawit yang relatif besar adalah di Kabupaten Jember yaitu sebesar 9,84 ribu ton atau $44,14 \%$ dari 22,28 ribu ton tahun 2013 menjadi 32,12 ribu ton pada tahun 2014. (BPS Jawa Timur, 2015).

Usahatani cabai rawit merupakan usahatani yang umum dilakukan oleh petani di Kecamatan Gumukmas Kabupaten Jember walaupun petani selalu dihadapkan pada keadaan yang tidak pada sisi harga cabai rawit. Pada tahun 20122015 fluktuasi harga di Kabupaten Jember mengalami fluktuasi yang sangat signifikan. Fluktuasi terjadi setiap bulan dalam satu tahun, harga tertinggi pada periode 2012-2015 dapat mencapai Rp.60.000,00 sedangkan untuk harga terendah mencapai dibawah Rp. 10.000,00 (Dinas Pertanian Kabupaten Jember, 2012-2015). Meskipun demikian, petani tetap mengusahakan cabai rawit 
karena cabai rawit sampai saat ini masih menjadi primadona bagi petani di Kabupaten Jember khususnya di wilayah Kecamatan Gumukmas. Oleh karena itu perlu dikaji karakteristik petani sebagai gambaran menyeluruh mengenai pelaku-pelaku usaha dimana hal tersebut akan berpengaruh pada perilaku petani dalam berusahatani, apakah berperilaku menolak, menerima, atau netral terhadap resiko dengan melihat harga yang diterima oleh petani pada satu kali panen. Penelitian ini secara garis besar dimaksudkan untuk mengetahui perilaku petani dalam menghadapi resiko fluktuasi harga.

\section{METODE PENELITIAN}

Lokasi penelitian ditentukan dengan sengaja di Kecamatan Gumukmas Kabupaten Jember dengan pertimbangan bahwa pada daerah tersebut merupakan sentra komoditas cabai rawit.

Penelitian ini menggunakan diskriptif, analitik. Metode diskriptif bertujuan untuk membuat deskripsi, gambaran, serta lukisan secara sitematik, faktual dan akurat megenai fakta-fakta, sifat-sifat serta hubungan antara fenomena yang diselidiki. Metode analitik berfungsi menguji hipotesa-hipotesa dan mengadakan interpretasi terhadap hasil analisa (Nazir, 2006).

Teknik pengambilan sampel petani secara acak sederhana (simple random sampling) sebesar 39 petani. Dari sampel terpilih dilakukan wawancara dengan kuisioner, teknik pencatatan dan observasi guna pengumpulan data.

Untuk mengkaji profil petani cabai rawit diperoleh melalui data primer melalui wawancara dan pengamatan langsung terhadap obyek penelitian, kemudian hasil analisis disajikan dalam bentuk tabel disertai penjelasan/uraian. Untuk mengetahui perilaku petani cabai rawit terhadap risiko fluktuasi harga (netral, menolak atau berani menanggung) digunakan prinsip Bernoulli dan Newman-Morgenstern (Soekartawi, 1993), dengan langkah-loangkah sebagai berikut:

a. Mencari fungsi utilitas yaitu fungsi hubungan antara utilitas dengan variabel bebas dari nilai rupiah $\mathrm{CE}$ dengan rumus sebagai berikut:

$$
\begin{aligned}
& \mathrm{U}=\mathrm{b}_{0}+\mathrm{b}_{1} \mathrm{M}_{1}+\mathrm{b}_{2} \mathrm{M}^{2 \mathrm{p}} \\
& \text { Keterangan; } \\
& \mathrm{U} \quad \text { : nilai utilitas } \\
& \mathrm{M} \quad \text { : nilai CE dalam rupiah } \\
& \mathrm{b} 0 \quad \text { : intersep } \\
& \mathrm{b}_{1}, \mathrm{~b}_{2}: \text { koefisen fungsi utilitas }
\end{aligned}
$$

b. Besarnya nilai koefisien fungsi utilitas $\left(b_{2}\right)$ menunjukkan perilaku tidak berani menghadapi resiko bagi petani cabai rawit, dengan suatu batasan:

- Pendugaan perilaku petani berani beresiko (risk lover) jika $\mathrm{b}_{2}>0$

- Pendugaan perilaku netral resiko (risk neutral) jika $b_{2}=0$

- Pendugaan perilaku tidak berani beresiko (risk averter) jika $\mathrm{b}_{2}<0$

Untuk menguji apakah petani mempunyai perilaku berani terhadap resiko atau tidak, diajukan hipotesis :

$\mathrm{H}_{0}: \mathrm{b}_{2}=0$

$\mathrm{H}_{1}: \mathrm{b}_{2}<0$

Hasil analisis dilakukan dengan menggunakan uji $-\mathrm{t}$ dengan rumus:

$$
\mathrm{t}_{\text {hitung }}=\frac{b_{2}}{\operatorname{Se}\left(b_{2}\right)}
$$

kriteria pengambilan keputusan adalah sebagai berikut :

- Jika $\mathrm{t}_{\text {hitung }}>\mathrm{t}_{\text {tabel }}$ maka $\mathrm{H}_{0}$ ditolak, berarti petani memiliki perilaku enggan terhadap resiko.

- Jika $t_{\text {hitung }}<t_{\text {tabel }}$ maka $H_{0}$ diterima, berarti petani memiliki perilaku berani terhadap resiko.

\section{HASIL DAN PEMBAHASAN \\ Karakteristik Petani Responden Di Keca- matan Gumukmas Kabupaten Jember}

Perilaku petani terhadap resiko fluktuasi harga terdiri dari tiga jenis perilaku yaitu perilaku petani yang menghindari resiko (risk averter), petani yang netral terhadap resiko (risk neutral), dan perilaku petani yang menyukai resiko (risk lover). Analisis resiko dapat menggambarkan keadaan ketidakpastian tentang suatu keadaan yang akan terjadi nantinya (future) dengan keputusan yang diambil berdasarkan berbagai pertimbangan pada saat ini. Hasil analisis resiko dapat memberikan keputusan terbaik dengan pengelolaan resiko. Penelitian ini dilakukan pada 39 responden (petani cabai rawit).

Rata-rata petani di Kecamatan Gumukmas memiliki umur produktif yaitu 47 tahun dengan rata-rata pengalaman bertani cabai rawit sebesar 18 tahun dan rata-rata jumlah anggota keluarga sebanyak 3 orang. Rata-rata luas lahan adalah 0,832 hektar artinya luas lahan yang dikelola petani untuk cabai rawit merupakan luas lahan dengan kategori sedang yaitu diatas 0,5 hektar. Rata-rata petani cabai rawit menempuh pendidikan selama 9 tahun atau setingkat dengan SMP, 
sedangkan untuk tingkat pendidikan terendah adalah 0 atau tidak pernah menempuh pendidikan formal, sedangkan yang tertinggi adalah 16 tahun atau setara Sarjana. Status kepemilikan lahan petani untuk melakukan usahatani dibedakan menjadi 4 status kepemilikan yaitu lahan milik sendiri, lahan sewa, lahan bagi hasil, dan lahan milik sendiri sekaligus sewa. Varietas yang diusahakan oleh petani terdiri dari dua varietas yaitu cabai rawit hibrida dan cabai rawit lokal.

Mayoritas petani cabai rawit di Kecamatan Gumukmas menanam cabai rawit lokal, alasannya adalah cabai rawit lokal mudah untuk dibudidayakan dan tidak memiliki perlakuan khusus. Pola tanam yang dilakukan oleh petani responden yaitu padi-cabai rawit- jagung dalam satu tahun. Selama pergiliran pola tanam cabai rawit ditanam pada bulan ke empat yaitu sekitar bulan April karena pada bulan tersebut curah hujan sudah mulai berkurang. Bulan April dipilih petani karena serangan penyakit dan hama juga semakin berkurang dan peningkatan biaya produksi tidak diperlukan, sehingga resiko gagal panen jadi semakin kecil. Selain pada bulan april ada juga petani menanam pada bulan Oktober, namun hal ini tidak selalu dilakukan. Resiko kegagalan panen sangat tinggi, karena pada bulan ini curah hujan mulai meningkat sehingga jumlah serangan penyakit dan hama sangat tinggi. Namun demikian, sebenarnya penanaman cabai rawit pada periode ini memungkinkan petani untuk mendapat harga tinggi, karena pasokan cabai rawit berkurang atau tidak sebanyak pada periode penanaman bulan april. Rata-rata jumlah produksi cabai rawit lokal selama satu musim tanam (7 kali panen) adalah kurang lebih sebesar 3-4 ton/ hektar sedangkan rata-rata jumlah produksi cabai rawit hibrida selama satu musim adalah 6-7 ton per hektar. Produksi cabai rawit hibrida memang lebih tinggi jika dibandingkan dengan cabai rawit lokal, karena cabai rawit hibrida lebih cepat panen dibandingkan dengan cabai rawit lokal.

\section{Perilaku Petani Dalam Menghadapi Resiko Fluktuasi Harga Di Kecamatan Gumukmas Kabupaten Jember}

Hasil penelitian mengenai perilaku petani cabai rawit di Kecamatan Gumukmas Kabupaten Jember di distribusikan berdasarakan hasil observasi dilapang. Distribusi tersebut dibagi menjadi distribusi perilaku petani secara umum, distribusi petani berdasarkan status kepemilikan lahan dan ditribusi perilaku petani berdasarkan varietas yang diusahakan oleh petani cabai rawit di Kecamatan Gumukmas Kabupaten Jember.

Hasil analisis sikap petani cabai rawit secara umum berdasarkan metode Bernoulli dan Neumann-Morgernstern dengan pendekatan nilai uang (harga) menunjukkan bahwa dari 39orang petani responden 25 petani responden memiliki koefisien arah $b_{2}$ negatif. Hal ini mengidentifikasikan adanya sikap keengganan petani menanggung resiko dalam berusahatani cabai rawit ketika terjadi fluktuasi harga. Selanjutnya dari hasil uji statistik menunjukkan 5 petani responden memiliki nilai koefisien arah $b_{2}$ negatif dan sangat signifikan pada taraf signifikanasi $90 \%$ dan $95 \%$, kelima petani responden tersebut benar-benar enggan enggan/ tidak berani dalam menghadapi resiko atau risk averter. Sedangkan 20 petani responden memiliki koefisien arah $b_{2}$ negatif dan tidak siginifikan pada taraf signifikansi $90 \%$ maupun $95 \%$, artinya pertani responden ini memiliki sikap netral terhadap resiko (risk neutral).

Petani responden yang memiliki nilai koefisien $b_{2}$ positif berjumlah 14 responden. Artinya petani responden memiliki sikap berani menanggung resiko dalam melakukan kegiatan usahatani ketika terjadi fluktuasi harga, namun uji statistik menunjukkan hanya 1 orang petani responden yang sangat signifikan pada taraf signifikansi $90 \%$. Artinya hanya ada 1 orang petani yang benar-benar berani dalam menghadapi resiko (risk lover). Sebanyak 13 petani sisanya menunjukkan koefisien $b_{2}$ positif akan tetapi setelah

Tabel 1. Distribusi Perilaku Petani Cabai Rawit di Kecamatan Gumukmas Terhadap Fluktuasi Harga Secara umum

\begin{tabular}{llrr}
\hline No & Perilaku Menghadapi Resiko & $\begin{array}{c}\text { Jumlah Responden } \\
\text { (orang) }\end{array}$ & Persentase (100\%) \\
\hline 1 & Risk Lover (Berani) & 1 & 2,56 \\
2 & Risk Neutral (Netral) & 33 & 84,62 \\
3 & Risk Averter (Tidak Berani) & 5 & 12,82 \\
\hline & Jumlah & 39 & 100 \\
\hline
\end{tabular}

Sumber: Analisis Data Primer, 2016 
diuji secara statistik hasilnya tidak signifikan pada taraf $90 \%$ ataupun $95 \%$ sehingga ketigabelas responden tersebut dapat dikatakan memiliki perilaku netral terhadap resiko (risk neutral).

Tabel 1. menunjukkan bahwa petani cabai rawit di Kecamatan Gumukmas Kabupaten Jember sebanyak 33 orang $(84,62 \%)$ responden memiliki perilaku netral terhadap resiko (risk neutral), sedangkan sebanyak 5 orang $(12,82$ $\%)$ responden memiliki perilaku enggan/tidak berani beresiko (risk averter), dan 1 orang (2,56 $\%)$ responden memiliki perilaku berani beresiko (risk lover).

Sebagaian besar petani memiliki perilaku risk neutral, hal ini dapat disebabkan oleh ketidakmampuan petani dalam memperoleh harga tinggi, hal ini didukung oleh fakta dilapang bahwa sebagaian besar petani menanam cabai rawit pada bulan april, seperti yang telah dikemukaan sebelumnya penanaman cabai rawit pada bulan ini cenderung menghasilkan harga yang tidak tinggi mengingat pasokan dipasar sangat tinggi. Alasan lain, petani telah terbiasa menghadapi resiko harga sehingga petani tidak menganggap resiko harga sebagai tantangan yang perlu dikhawatirkan.

Penelitian Hartati (2007), menunjukkan bahwa jumlah anggota keluarga petani sangat berpengaruh terhadap sikap/ perilaku petani dalam mengahadapi resiko, semakin banyak jumlah anggota keluarga maka petani semakin berani dalam menanggung resiko. Keadaan ini menunjukkan bahwa dengan semakin banyaknya anggota keluarga maka kebutuhan juga semakin meningkat sehingga menuntut petani untuk lebih giat bekerja, berkorban lebih besar untuk meraih hasil yang lebih baik, sehingga menimbulkan keinginan untuk berperilaku berani untuk menanggug resiko. Mengacu pada penelitian Hartati tersebut maka dapat dipahami mengapa petani lebih banyak bersikap netral (risk neutral) karena rata-rata petani memiliki jumlah anggota keluarga sebanyak 3 orang, sedangkan satu-satunya responden yang berani yaitu Bapak Atmari memiliki jumlah anggota keluarga sebanyak 5 orang, sehingga memacu sikap berani terhadap resiko fluktuasi harga cabai rawit.

Hartati (2007) juga menyatakan bahwa semakin luas lahan garapan yang diusahakan petani maka petani akan semakin berani menanggung resiko. Mengacu pada hasil penelitian tersebut maka tidak aneh jika hasil penelitian ini sebagaian besar petani bersikap netral resiko (risk neu- tral). Hal ini dikarenakan rata-rata petani hanya memiliki lahan dengan skala sedang yaitu lebih dari 0,5 Ha.

Pada penjelasan selanjutnya perilaku petani dalam menghadapi resiko fluktuasi harga akan didistribusikan berdasarkan status kepemilikan lahan. Hasil analisis petani cabai rawit dalam menghadapi resiko fluktuasi harga setelah diditribusikan berdasarkan status kepemilikan lahan adalah sebanyak 25 responden dari 39 responden memiliki koefisien $b_{2}$ negatif kemudian dari ke 39 respoden tersebut di distribusikan dengan segmentasi petani dengan kepemilikan lahan sendiri sebanyak 22 responden, petani dengan lahan sewa sebanyak 8 orang, petani dengan status kepemilikan lahan bagi hasil sebanyak 5 orang, dan petani yang memilki kepemilikanlahan sekaligus adalah sebanyak 4 orang. Petani dengan status kepemilikan lahan sendiri memiliki 13 responden yang memiliki koefisien $b_{2}$ negatif dengan 2 orang responden yang memiliki koefisien b2 negatif yang sangat signifikan pada taraf signifikansi $90 \%$ dapat dikatakan bahwa kedua responden tersebut benar-benar tidak berani terhadap resiko (risk averter), sedangkan sisanya sebanyak 11 orang responden tidak signifikan pada taraf signifkansi $90 \%$ atau dapat dikatakan responden tersebut ber perilaku netral terhadap resiko (risk neutral). Petani dengan kepemilikan lahan sendiri memiliki 9 orang responden yang memiliki koefisien $b_{2}$ positif, dengan 1 orang responden yang sangat signifikan pada tingkat kepercayaan $90 \%$ atau dapat dikatakan petani tersebut berani terhadap resiko (risk lover) dan 8 orang lainnya memiliki koefisien b2 positif yang tidak signifikan terhadap taraf kepercayaan $90 \%$ maka dapat dikatakan 8 orang responden tersebut netral terhadap resiko (risk neutral).

Petani dengan kepemilikan lahan sewa memiliki 8 orang responden dengan 5 orang diantara mermiliki koefisien $b_{2}$ negatif dan 3 orang lainnya memiliki nilai koefisien $b_{2}$ positif. Lima (5) orang petani yang memiliki koefisien $\mathrm{b}_{2}$ negatif 4 orang diantaranya tidak signifikan pada taraf kepercayaan 90\% (risk neutral) sedangkan hanya 1 orang yang signifikan (risk averter). Petani dengan koefisien $b_{2}$ positif sebanyak 3 orang semuanya tidak signifikan pada taraf kepercayaan 90\% (risk neutral).

Petani dengan kepemilikan lahan bagi hasil memiliki 5 orang responden yang semuanya memiliki koefisien $b_{2}$ negatif, dua diantaranya 
signifikan pada taraf kepercayaan $90 \%$ artinya kedua petani tersebut benar-benar tidak berani menghadapi resiko (risk averter) sedangkan sisanya sebanyak 3 orang tidak signifikan pada taraf kepercayaan $90 \%$ atau dapat dikatakan (risk avereter).

Petani dengan kepemilikan lahan ganda yaitu milik sendiri dan sewa memiliki 2 orang responden dengan koefisien $b_{2}$ negatif dan 2 orang responden dengan koefisien positif. Setelah diuji dengan uji statistik semua responden tersebut tidak signifikan pada taraf kepercayaan $90 \%$ maka dengan kata lain semua responden netral terhadap resiko (risk neutral).

Tabel 2. menunjukkan bahwa pada status kepemilikan lahan sendiri petani berperilaku tidak berani sampai berani yakni, sebanyak 19 petani berperilaku netral terhadap resiko (risk neutral), 2 petani enggan/tidak berani beresiko (risk averter), dan 1 orang berani terhadap resiko (risk lover).

Petani dengan status kepemilikan lahan sewa memiliki perilaku tidak berani hingga netral yaitu sebanyak 1 orang responden berperilaku enggan/tidak berani beresiko (risk averter), dan 7 orang responden berperilaku netral (risk neutral).

Petani dengan status kepemilikan lahan bagi hasil memiliki perilaku enggan/tidak berani beresiko sampai netral yaitu, sebanyak 2 orang responden enggan/tidak berani beresiko (risk averter), dan 3 orang petani lainnya berperilaku netral (risk neutral).

Petani dengan dua status kepemilikan lahan sekalaigus sebanyak 4 orang responden semuanya berperilaku netral terhadap resiko (risk neutral).

Berdasarkan tabel 2 maka dapat diketahui bahwa status kepemilikan lahan berpengaruhh terhadap perilaku petani dalam menghadapi resiko. Petani dengan status kepemilikan lahan sendiri lebih berani dibandingkan dengan petani yang memiliki status kepemilikan lahan sewa, bagi hasil atau status kepemilikan lahan ganda (sendiri dan sewa).

Hal ini sesuai dengan hasil penelitian dari Hartati (2007), bahwa sebagai pemilik petani lebih berani menanggung resiko karena kepastian penggunaan lahan memberikan kemungkinan yang meyakinkan kepada petani untuk melakukan investasi di atas lahan miliknya sendiri. kepastian kepemilikan lahan dapat memberikan kebebasan kepada petani untuk mengusahakan dan mengembangkan usahataninya, karena adanya rasa tanggung jawab yang besar terhadap lahan miliknya. Perilaku enggan ini dikarenakan petani-petani tersebut harus membayar biaya lebih untuk sewa, sedangkan bagi petani lahan bagi hasil dipengaruhi oleh sebagaian besar biaya usahatani yang dibebankan kepada petani penggarap, sedangkan untuk hasil tetap dibagi masing masing 50 persen antara pemilik lahan dan petani penggarap. Jika terjadi penurunan harga secara signifikan maka petani penggarap akan berada pada posisi yang sulit, hal inilah yang menjadi dasar sikap hati-hati petani dengan status kepemilikan lahan bagi hasil.

Penetuan varietas yang ditanam dalam melakukan kegiatan usahatani juga mempengaruhi petani dalam berperilaku ketika mengahadapi fluktuasi harga cabai rawit. Hasil penelitian dengan menggunakan metode Bernoulli dan Neumann-Morgernstern menunjukkan bahwa setelah didistribusikan, petani yang menanam varietas hibrida sebanyak 8 orang responden 4 orang diantaranya memiliki nilai koefisien $b_{2}$ negatif dengan 1 orang petani responden memiliki signifikansi yang nyata pada taraf kepercayaan $90 \%$,dapat dikatakan petani tersebut memiliki perilaku tidak berani beresiko (risk averter), sedangkan 3 orang lainnya tidak signifikan pada taraf kepercayaan $90 \%$ atau dapat dikatakan petani tersebut memiliki perilaku netral terhadap

Tabel 2. Distribusi Petani Yang Memiliki Perilaku Risk Averter, Risk Neutral,Risk Lover Berdasarkan Status Kepemilikan Lahan

\begin{tabular}{lrrrr}
\hline \multirow{2}{*}{$\begin{array}{l}\text { Status Kepemilikan } \\
\text { lahan Petani }\end{array}$} & \multicolumn{3}{c}{ Perilaku Terhadap Resiko } & \multirow{2}{*}{ Jumlah orang } \\
\cline { 2 - 4 } Sendiri & 2 & Risk Neutral (orang) & Risk Lover (orang) & 22 \\
Sewa & 1 & 19 & 1 & 8 \\
Bagi hasil & 2 & 3 & - & 5 \\
Sendiri dan Sewa & - & 4 & - & 4 \\
\hline Jumlah & 5 & 33 & 1 & 39 \\
$\%$ & $12,82 \%$ & $84,62 \%$ & $2,56 \%$ & $100 \%$ \\
\hline
\end{tabular}

Sumber : Analisis data primer, 2016. 
resiko (risk neutral). Sisanya sebanyak 4 orang petani memiliki nilai koefisien $b_{2}$ positif yang semuanya tidak signifikan pada taraf kepercayaan 90\% atau netral terhadap resiko (risk neutral).

Petani dengan varietas lokal sebanyak 25 petani, 16 diantaranya memiliki nilai koefisien $b_{2}$ negatif dengan 4 orang petani responden memiliki signifikansi yang nyata pada taraf kepercyaan $90 \%$ atau dapat dikatakan petani tersebut memiliki perilaku tidak berani terhadap resiko (risk averter), sedangkan 12 orang responden lainnya tidak signifikan pada taraf kepercayaan $90 \%$ atau dapat dikatakan bahwa keduabelas petani tersebut netral terhadap resiko (risk neutral). Sisanya sebanyak 9 orang petani memiliki nilai koefisien $\mathrm{b}_{2}$ positif dengan 1 orang petani memiliki signifikansi yang nyata pada taraf kepercayaan 90\% sehingga dapat dikatakan petani responden tersebut berperilaku berani beresiko (risk lover) dan 8 orang petani lainnya tidak signifikan pada taraf kepercayaan $90 \%$ sehingga dapat dikatakan bahwa petani tersebut memiliki perilaku yang netral terhadap resiko (risk neutral).

Petani yang menanam dua varietas sekaligus sebanyak 6 orang petani, 5 orang diantaranya memiliki nilai $b_{2}$ negatif dan 1 orang memiliki nilai koefisienb ${ }_{2}$ positif yang semuanya tidak signifikan pada taraf kepercayaan $90 \%$, atau dapat dikatakan petani yang menanam dua varietas sekaligus semua memiliki perilaku yang netral terhadap resiko (risk neutral).

Tabel 3 menunjukkan bahwa terdapat perbedaan perilaku pada petani yang mengusahakan varietas hibrida, lokal dan keduanya. Petani yang mengusahakan varietas hibrida memiliki perilaku netral sampai tidak berani beresiko, yaitu sebanyak 7 orang petani responden memiliki perilaku netral terhadap resiko (risk neutral), dan 1 orang petani memiliki perilaku tidak berani terhadap resiko (risk averter).
Petani dengan varietas cabai rawit lokal memiliki perilaku berani beresiko sampai tidak berani berani beresiko, yaitu sebanyak 1 orang petani berperilaku berani terhadap resiko (risk lover), 20 orang petani responden memiliki perilaku netral terhadap resiko (risk neutral), dan 4 orang petani memiliki perilaku tidak berani terhadap resiko (risk averter).

Petani yang mengusahakan dua varietas sekaligus memiliki perilaku yang netral dimana semua responden sebanyak 6 orang petani memiliki perilaku netral terhadap resiko (risk neutral).

Hasil distribusi tersebut menunjukkan bahwa keputusan petani dalam menanam jenis varietas berpengaruh terhadap perilaku petani dalam menghadapi resiko fluktuasi harga cabai rawit. Petani yang menanam varietas lokal lebih berani dibandingkan dengan petani yang menanam varietas hibrida dan petani yang menanam dua varietas sekaligus. Petani yang mengusahakan varietas lokal lebih berani karena biaya yang dikeluarkan petani tidak sebanyak yang dikeluarkan oleh petani hibrida. Biaya usahatani varietas lokal berkisar Rp.7.864.750,- per Ha, sedangkan petani cabai rawit hibrida harus mengeluarkan biaya sebesar Rp. 19.828.000,- untuk melakukan usahatani. Petani menempatkan komoditas cabai rawit sebagai tanaman utama dalam usahataninya, walaupun ketika terjadi fluktuasi harga petani akan beralih menanam komoditi lain walau hanya untuk sementara setelah harga kembali normal atau ketika harga stabil petani akan menanam cabai rawit kembali. Sedangkan, petani yang mengusahakan cabai rawit hibrida menolak resiko karena dipengnaruhi oleh keengganan petani dalam menggunakan modal yang besar untuk pembelian plastik mulsa dan pupuk bukan subsidi. Penggunaan biaya yang dibebankan pada penggunaan pupuk non subsidi yang besar ini tidak harus dilakukan akan

Tabel 3. Distribusi Petani Yang Memiliki Perilaku Risk Averter, Risk Neutral, Risk Lover Berdasarkan Varietas Cabai Rawit Yang Ditanam

\begin{tabular}{lrrrr}
\hline \multirow{2}{*}{ Jenis Varietas Cabai Rawit } & \multicolumn{3}{c}{ Perilaku Terhadap Resiko } & Jumlah orang \\
\cline { 2 - 5 } & \multicolumn{1}{c}{ Risk Averter (orang) } & Risk Neutral (orang) & Risk Lover (orang) & \\
\hline Hibrida & 1 & 7 & - & 8 \\
Lokal & 4 & 20 & 1 & 25 \\
Hibrida dan Lokal & - & 6 & - & 6 \\
\hline Jumlah & 5 & 33 & 1 & 39 \\
\hline$\%$ & $12,82 \%$ & $84,62 \%$ & $2,56 \%$ & \\
\hline
\end{tabular}

Sumber : Analisis data primer, 2016. 
tetapi untuk hasil yang maksimal maka hal ini perlu dilakukan. Perilaku netral petani ini didasari oleh kesulitan petani jika terjadi penurunan harga yang sering menyerang cabai rawit selain itu hal tersebut juga didasari pengalaman usahatani cabai rawit hibrida yang kurang, karena memang cabai hibrida baru diperkenalkan sejak tahun 2012. Petani seharusnya tidak perlu khawatir karena dengan menanam dua jenis varietas maka petani dapat mengandalkan salah satu varietas jika harga salah satu jenis varietas jatuh.

\section{KESIMPULAN}

Secara keseluruhan sebagian besar petani $(84,62$ \%) cabai rawit berperilaku netral terhadap risiko harga (risk neutral) selebihnya, sebanyak 12,82 $\%$ petani tidak berani terhadap risiko fluktuasi harga (risk averter), dan 2,56\% petani berani menghadapi risiko (risk lover). Berdasarkan status kepemilikan lahan, petani dengan lahan milik sendiri memiliki perilaku yang lebih berani dibandingkan dengan petani yang memiliki status kepemilikan lahan sewa, bagi hasil, atau yang memiliki dua status kepemilikan lahan sekaligus yaitu milik sendiri dan sewa.Keputusan petani dalam memilih varietas untuk diusahakan berengaruh terhadap perilaku petani dalam menghadapi risiko fluktuasi harga, petani yang mengusahakan varietas lokal lebih berani dibandingkan dengan petani yang mengusahakan varietas hibrida ataupun petani yang menngusahakan kedua varietas tersebut sekaligus.

\section{DAFTAR PUSTAKA}

Bps Jatim 2014. Statistik Hortikultura. [Serial Online]. Http://Hortikultura.Pertanian.Go.Id/ Wp-Content/Uploads/2016/02/Statistik-Produksi-2014.Pdf. [27.Desember 2015]

Hartati, Anny.2007. Pengaruh Perilaku Petani Terhadap Risiko Keefisienan Sahatani Kentang Di Kabupaten Wonosobo Jawa Tengah. Agroland. 14(3): 165-171

Nazir, Moh. 2006. Metode penelitian. Bogor: Ghalia Indonesia

Soekartawi, Rusinadi, Effi Damaijati. 1993. Risiko Dan Ketidakpastian Dalam Agribisnis. Jakarta : Raja Grafindo Persada 